\title{
Elementary, Middle and High School Parents' Awareness of School Garden Education Service
}

\author{
In-Kyoung Hong ${ }^{1}$, Hyung-Kwon Yun ${ }^{2 *}$, Young-Bin Jung ${ }^{3}$, Sang-Mi Lee ${ }^{3}$, and Choon-soo Lee ${ }^{4}$ \\ ${ }_{1}^{1}$ Postdoctoral researcher, Urban Agricultural Research Division, National Institute of Horticultural and Herbal Science, Rural Development \\ Administration, Wanju-gun, Jeolabuk-do 55365, Korea \\ ${ }^{2}$ Senior researcher, Urban Agricultural Research Division, National Institute of Horticultural and Herbal Science, Rural Development \\ Administration, Wanju-gun, Jeolabuk-do 55365, Korea \\ ${ }^{3}$ Researcher, Urban Agricultural Research Division, National Institute of Horticultural and Herbal Science, Rural Development Administration, \\ Wanju-gun, Jeolabuk-do 55365, Korea \\ ${ }^{4}$ Professor, Department of Agricultural Economics, Suncheon University, Suncheon 57922, Korea
}

\section{ABSTRACT}

Background and objective: Education based on agricultural experience in school gardens is coming to the fore as a solution to reduce the negative effect of rapid urbanization and the development of information technology (IT) on students. Accordingly, this study aimed to investigate how parents of elementary, middle, and high school students in Korea perceive the value of education service using school gardens, as well as their willingness to participate in and pay for such service, and to utilize the results in a quantitative assessment of the socioeconomic value of the education service.

Methods: A contactless online survey on the perceived value of education service using school gardens was conducted on 1,010 parents of elementary, middle, and high school students in Korea's five major districts from October 22 to 26 ( 5 days) of 2020 by M, a Korean specialized survey agency. The data collected was analyzed using SPSS for Windows 25.0 and Excel to obtain the frequency and ratio of each measured item.

Results: The respondents had an average of 1.83 , of which $52.8 \%$ were male. $55.3 \%$ of the respondents were aware of the education service using school gardens, and $27.9 \%$ experienced the service. When asked if they saw the educational service using school gardens as necessary, $79 \%$ answered in the affirmative. In terms of the difference in perception of the need for the service according to experience, $91.8 \%$ of the parents who experienced the service responded that it was necessary, indicating that it is important to provide opportunities to experience this service to expand the scope of service. $54.9 \%$ of all respondents responded they were willing to pay the costs required for school gardens. When income tax was used as a payment method, the average amount parents were willing to pay was $13,193 \mathrm{KRW}$, and the tax rate was $2.02 \%$. Based on experience, those who experienced this service had a higher need and willingness to pay for the service than those who had not experience, but the actual amount or tax rate was low as they knew how it was operated.

Conclusion: As basic research on the assessment of the value of agricultural experience education using school gardens, this study determined how parents perceive this form of education service as well as their willingness to participate and pay for the service. These findings can be used to systemize the assessment indicators and promote the value of the education service using school gardens, allowing students to maintain a healthy and happy school life through agricultural experience.

Keywords: agricultural experience, intent to participation, urban agriculture, value evaluation, willingness to pay

\section{Introduction}

Rapid urbanization reduced the opportunities for stu- dents living in the city to encounter nature, and increased contact with virtual reality rather than the natural environment due to IT development has a negative impact on prop-

\footnotetext{
This study is funded by the Rural Development Administration Project (PJ01364403).

Received: February 15, 2021, Revised: February 24, 2021, Accepted: March 14, 2021

First author: In-Kyoung Hong, inkyoung63@korea.kr, (10) https://orcid.org/0000-0002-7050-5413

*Corresponding author: Hyung-Kwon Yun, yun0309@korea.kr, (1) https://orcid.org/0000-0001-9973-4706
} 
er character education, such as school violence (GGC, 2012). Thus, the need to provide opportunities to easily enjoy green experiences within school grounds has been raised to enlighten students with the preciousness of nature, environment, and energy while also cultivating a balanced character. As an alternative, agricultural experience-based education using 'school gardens' is receiving attention (Jang et al., 2017). Agricultural activities experienced within school grounds not only reduce stress of students and improve their health, concentration and social skills but also promote understanding about agriculture and rural areas (Kwack and Park, 2017).

School gardens have been valued as an educational tool since the 18th-century Europe until today, referring to the green space created within school grounds with many philosophers emphasizing the importance of sensory experiences (GGC, 2012). Article 8, paragraph (1)-5 of the Act on Development and Support of Urban Agriculture defines urban agriculture for school education as urban agriculture by utilizing the land or building of a school for students' learning and practice. Therefore, school garden education service is s service providing various education programs about nutrition, dietary life, and cultural events along with agricultural experience. According to the 'Survey on Actual Conditions of Urban Agriculture (operation status of school gardens)' conducted by the Seoul Metropolitan Office of Education in 2012, 66.8\% of elementary schools in Seoul have school gardens (Kim, 2014), and nearly half the population of urban agricultural is participating in 'urban agriculture for school education' defined in the Act on Development and Support of Urban Agriculture (MAFRA, 2017). As such, various effects of activities using school gardens have been reported, and education programs based on various gardening activities improve students' responsibility, sense of accomplishment, confidence, stability, social skills, and peer relations, thereby having positive effects on character cultivation as well (Kim and Jeong, 2008; Jeong and Lee, 2013; Hong and Kim, 2017). Thus, continuous expansion of school garden education is needed, but there were issues such as difficulty in securing space, additional operating expenses, negative opinions among parents about gardening activities, and low educational use. Furthermore, there are almost no studies on the values of school garden education service aside from Hong et al. (2020), and thus there is an urgent need to develop evaluation indicators for value expansion of agricultural experience to create a healthy and happy school life for students. Accordingly, as a basic study to derive evaluation indicators, we extracted samples with proportionate sampling in 5 major districts in Korea and conducted a survey on parents of elementary, middle, and high school students to determine their awareness of the value of school garden education service as well as their intent to participate and willingness to pay. The results of this study will be used in evaluation of quantitative socioeconomic values of school garden education service in the future.

\section{Research Methods}

\section{Subjects and methods}

To examine parents' awareness of school garden education service, we conducted a survey on 1,010 parents of elementary, middle, and high school students in the 5 major districts from October 22 to 26, 2020 (5 days). The questionnaire was distributed after determining whether there are children under age 18 attending elementary, middle, or high school. To avoid redundancy of survey respondents, the sample size of parents with multiple children was adjusted based on gender and grade of the first child. To secure sample representativeness, we selected the samples by proportionate sampling by region through a Korean specialized survey agency $\mathrm{M}$ located in Seoul, and conducted a contactless online survey considering the COVID-19 situation.

\section{Contents}

The survey items were comprised of total 7 items of demographic characteristics such as gender, age, residence, occupation, highest level of education, monthly income, number of children, child's gender, and child's grade. To smoothly conduct this study, the purpose and contents of the survey as well as the concept of education-based agricultural experience service using school gardens were suffi- 
ciently described in the questionnaire, after which we organized the survey with 3 items such as awareness of the relevant contents, necessity, and participation experience, and 3 items such as willingness to pay for expenses in creating gardens, installing amenities, operating various education programs, and installing other facilities, the maximum amount they are willing to pay, and the willingness to additionally pay for the increased individual consumption tax used as a finance for educational taxes to cover the expenses. For maximum amount and individual consumption tax rate the respondents are willing to pay, the respondents were to provide responses in the form of a self-report test.

\section{Data analysis}

From 1,010 copies of the questionnaire collected, we obtained the frequency and weight of each measurement item using SPSS for Windows 25.0 and Excel 2016. A frequency analysis was conducted on demographic characteristics such as gender, age, residence, occupation, highest level of education, monthly income, number of children and their grade. The difference in the awareness of school garden education service was surveyed using a 5-point Likert scale. The respondents were to rate the items on a scale of 1 to 5 , with higher scores indicating that they are better aware. A paired sample t-test was conducted to determine the necessity of the school garden education service based on experience. The means of pros and cons of education service, intent to participate, and willingness to pay were obtained, and one-way ANOVA was conducted to determine the willingness to pay based on experience.

\section{Results and Discussion}

\section{Demographic characteristics of respondents}

There were 494 male (48.9\%) and 516 female (51.1\%) respondents, with slightly more women than men. Most of the respondents were in their 40s $(722,71.5 \%)$, followed by 30 s and below $(168,16.6 \%)$ and 50s $(120,11.9 \%) .359$ respondents (35.5\%) lived in Gyeonggi/Gangwon/Incheon, followed by 158 in Seoul (15.6\%), 156 in Busan/Ulsan/ Gyeongnam (15.4\%), 122 in Gwangju/Jeonbuk/Jeonnam/ Jeju (12.1\%), 115 in Daejeon/Sejong/Chungbuk/Chungnam (11.4\%), and 100 in Daegu/Gyeongbuk (9.9\%). Most were salaried employees $(577,57.1 \%)$, followed by homemakers (214, 21.2\%), self-employed (82, 8.1\%), specialized professions $(66,6.5 \%)$, government officials $(41,4.1 \%)$, others $(29,2.9 \%)$, and student $(1,0.1 \%)$. Others included various responses such as daycare teachers, social workers, salesclerks, special workers, freelancers, religious professions, and unemployed. For highest level of education, most were university students/graduates $(755,74.8 \%)$, followed by high school graduates $(140,13.9 \%)$, graduate school or higher $(114,11.3 \%)$, and middle school graduate or lower $(1,0.1 \%)$. For average monthly income, most respondents earned 4-4.99 million KRW (230, 22.8\%), followed by 5-5.99 million KRW (189, 18.7\%), 3-3.99 million KRW (164, 16.2\%), 6-6.99 million KRW (115, 11.4\%), 7-7.99 million KRW (94, 9.3\%), 2-2.99 million KRW \& 8-8.99 million KRW (62, 6.1\%), 10 million KRW and higher (49, $4.9 \%)$, 9-9.99 million $\mathrm{KRW}(28,2.8 \%), 1-1.99$ million KRW (13, 1.3\%), and lower than 1 million KRW (4, 0.4\%). For the child's gender, there were more male children (533, $52.8 \%$ ) than female $(477,47.2 \%)$, and the average number of children was 1.83 (1.75 in elementary school, 1.86 in middle school, 1.88 in high school) (Table 1).

\section{A survey on parents' awareness of school garden education service}

As a result of asking the respondents about whether they are aware of school garden education service, 55.3\% (558) responded that they have heard of it and are well aware, whereas $44.7 \%$ (452) barely knew about it. This is quite different from the study by RDA (2014) showing that more than $90 \%$ of respondents were aware of school gardens. This may be due to the different opinions from understanding education service separately from garden space. Thus, it is necessary to seek qualitative improvement of space for education service by aligning this service with programs that can increase satisfaction and interest. The mean of the awareness of education-based agricultural experience service using school gardens was 2.66 (2.65 in 
Table 1. Demographic characteristics of the research subject.

[unit: number(\%)]

\begin{tabular}{|c|c|c|c|c|c|}
\hline & Item & Elementary & Middle & High & Total \\
\hline \multirow{2}{*}{ Gender } & Male & $164(46.5)$ & $160(48.9)$ & $170(51.5)$ & 494(48.9) \\
\hline & Female & $189(53.5)$ & $167(51.1)$ & $160(48.5)$ & $516(51.1)$ \\
\hline \multirow{3}{*}{ Age } & Under 30 & $135(38.2)$ & $23(7.0)$ & $10(3.0)$ & $168(16.6)$ \\
\hline & $40 \mathrm{~s}$ & 208(58.9) & $277(84.7)$ & $237(71.8)$ & $722(71.5)$ \\
\hline & $50 \mathrm{~s}$ & $10(2.8)$ & $27(8.3)$ & $83(25.2)$ & $120(11.9)$ \\
\hline \multirow{6}{*}{ Residence } & Seoul & $54(15.3)$ & $51(15.6)$ & $53(16.1)$ & $158(15.6)$ \\
\hline & Kyeonggi/Gangwon/Incheon & $128(36.3)$ & $117(35.8)$ & $114(34.5)$ & $359(35.5)$ \\
\hline & Daejeon/Sejong/Chungbuk/Chungnam & $40(11.3)$ & $37(11.3)$ & $38(11.5)$ & $115(11.4)$ \\
\hline & Gwangju/Jeonbuk/Jeonnam/Jeju & $42(11.9)$ & $41(12.5)$ & $39(11.8)$ & $122(12.1)$ \\
\hline & Dae-gu/Gyeongbuk & $33(9.3)$ & $32(9.8)$ & $35(10.6)$ & $100(9.9)$ \\
\hline & Busan/Ulsan/Gyeongnam & $56(15.9)$ & $49(15.0)$ & $51(15.5)$ & $156(15.4)$ \\
\hline \multirow{7}{*}{ Occupation } & Salaried employees & $213(60.3)$ & $189(57.8)$ & $175(53.0)$ & $577(57.1)$ \\
\hline & Self-employed & $24(6.8)$ & $23(7.0)$ & $35(10.6)$ & $82(8.1)$ \\
\hline & Specialized professions & $24(6.8)$ & $15(4.6)$ & $27(8.2)$ & $66(6.5)$ \\
\hline & Government official & $14(4.0)$ & $11(3.4)$ & $16(4.8)$ & $41(4.1)$ \\
\hline & Homemakers & $71(20.1)$ & $76(23.2)$ & $67(20.3)$ & $214(21.2)$ \\
\hline & Students & $0(0.0)$ & $1(0.3)$ & $0(0.0)$ & $1(0.1)$ \\
\hline & Other & $7(2.0)$ & $12(3.7)$ & $10(3.0)$ & $29(2.9)$ \\
\hline \multirow{4}{*}{$\begin{array}{l}\text { Highest level } \\
\text { of education }\end{array}$} & Middle school graduate & $0(0.0)$ & $1(0.3)$ & $0(0.0)$ & $1(0.1)$ \\
\hline & High school graduate & $37(10.5)$ & $45(13.8)$ & $58(17.6)$ & $140(13.9)$ \\
\hline & University graduate & $274(77.6)$ & $247(75.5)$ & $234(70.9)$ & $755(74.8)$ \\
\hline & Graduate school or higher & $42(11.9)$ & $34(10.4)$ & $38(11.5)$ & $114(11.3)$ \\
\hline \multirow{11}{*}{$\begin{array}{l}\text { Monthly } \\
\text { income }\end{array}$} & Less then 1 million won & $2(0.6)$ & $1(0.3)$ & $1(0.3)$ & $4(0.4)$ \\
\hline & $1,000,000-1,990,000$ won & $6(1.7)$ & $3(0.9)$ & $4(1.2)$ & $13(1.3)$ \\
\hline & $2,000,000-2,990,000$ won & $22(6.2)$ & $22(6.7)$ & $18(5.5)$ & $62(6.1)$ \\
\hline & $3,000,000-3,990,000$ won & $69(19.5)$ & $51(15.6)$ & $44(13.3)$ & $164(16.2)$ \\
\hline & $4,000,000-4,990,000$ won & $78(22.1)$ & $76(23.2)$ & $76(23.0)$ & $230(22.8)$ \\
\hline & $5,000,000-5,990,000$ won & $68(19.3)$ & $44(13.5)$ & $77(23.3)$ & $189(18.7)$ \\
\hline & $6,000,000-6,990,000$ won & $34(9.6)$ & $46(14.1)$ & $35(10.6)$ & $115(11.4)$ \\
\hline & $7,000,000-7,990,000$ won & $37(10.5)$ & $29(8.9)$ & $28(8.5)$ & $94(9.3)$ \\
\hline & $8,000,000-8,990,000$ won & $20(5.7)$ & $22(6.7)$ & $20(6.1)$ & $62(6.1)$ \\
\hline & $9,000,000-9,990,000$ won & $6(1.7)$ & $14(4.3)$ & $8(2.4)$ & $28(2.8)$ \\
\hline & 10 million won or more & $11(3.1)$ & $19(5.8)$ & $19(5.8)$ & $49(4.9)$ \\
\hline \multirow{2}{*}{ Child gender } & Male & $180(51.0)$ & $170(52.0)$ & $183(55.5)$ & $533(52.8)$ \\
\hline & Female & $173(49.0)$ & $157(48.0)$ & $147(44.5)$ & $477(47.2)$ \\
\hline
\end{tabular}

elementary school, 2.69 in middle school, 2.65 in high school) out of 5 , which was low at below average and showing no statistically significant difference $(p=.889$, Table 2).

282 respondents $(27.9 \%)$ said they have experienced school garden education service. This is different from the study by Kim (2014) showing that only $62 \%$ of the parents who experienced gardening activities also have experience participating in school gardens. This indicates that there is an urgent need for development of new programs aligning school education with gardening activities in addition to plant cultivation as well as publicity to expand the scope 
Table 2. Awareness level of school garden education service.

(unit: number(\%))

\begin{tabular}{crrrrrrrr}
\hline \multirow{2}{*}{ Item $^{\mathrm{z}}$} & \multicolumn{9}{c}{ Awareness level $^{\mathrm{y}}$} & \multirow{2}{*}{ Mean \pm SD } & F & Significant \\
\cline { 2 - 6 } & \multicolumn{1}{c}{$\mathrm{y} 1$} & $\mathrm{y} 2$ & $\mathrm{y} 3$ & $\mathrm{y} 4$ & $\mathrm{y} 5$ & & \\
\hline $\mathrm{x} 1$ & $60(17.0)$ & $97(27.5)$ & $115(32.6)$ & $69(19.5)$ & $12(3.4)$ & $2.65 \pm 1.08$ & \\
$\mathrm{x} 2$ & $61(18.7)$ & $91(27.8)$ & $86(26.3)$ & $67(20.5)$ & $22(6.7)$ & $2.69 \pm 1.19$ & 0.118 & $.889^{\text {NS }}$ \\
x3 & $65(19.7)$ & $78(23.6)$ & $106(32.1)$ & $68(20.6)$ & $13(3.9)$ & $2.65 \pm 1.13$ & \\
Total & $186(18.4)$ & $266(26.3)$ & $307(30.4)$ & $204(20.2)$ & $47(4.7)$ & $2.66 \pm 1.13$ & \\
\hline
\end{tabular}

Note. Values are mean (standard deviation).

${ }^{\mathrm{z}} \mathrm{x} 1$ = Elementary school; $\mathrm{x} 2$ = Middle school; $\mathrm{x} 3$ = High school.

${ }^{\mathrm{y}} \mathrm{y}=$ No idea; $\mathrm{y} 2$ = Hardly know; $\mathrm{y} 3=$ Heard; $\mathrm{y} 4=$ Know a little; $\mathrm{y} 5=$ Know well.

${ }^{\mathrm{NS}}$ Non-significant by ANOVA test.

Table 3. Recognition of experience and necessity of school garden education service.

(unit: number(\%))

\begin{tabular}{|c|c|c|c|c|c|c|c|}
\hline \multirow{2}{*}{ Division } & \multirow{2}{*}{ Item $^{\mathrm{z}}$} & \multicolumn{3}{|c|}{ Recognition $^{\mathrm{y}}$} & \multirow{2}{*}{ Mean \pm SD } & \multirow{2}{*}{$\mathrm{F}$} & \multirow{2}{*}{ Significant } \\
\hline & & $\mathrm{y} 1$ & & $y 2$ & & & \\
\hline \multirow{4}{*}{ Experience } & $\mathrm{x} 1$ & $98(27.8)$ & & $255(72.2)$ & $1.72 \pm 0.45$ & \multirow{4}{*}{1.075} & \multirow{4}{*}{$.342^{\mathrm{NS}}$} \\
\hline & $\mathrm{x} 2$ & $100(30.6)$ & & $227(69.4)$ & $1.69 \pm 0.46$ & & \\
\hline & $\mathrm{x} 3$ & $84(25.5)$ & & $246(74.5)$ & $1.75 \pm 0.44$ & & \\
\hline & Total & $282(27.9)$ & & $728(72.1)$ & $1.72 \pm 0.45$ & & \\
\hline Division & Item $^{z}$ & $\mathrm{y} 3$ & $\mathrm{y} 4$ & y5 & Mean \pm SD & $\mathrm{F}$ & Significant \\
\hline \multirow{4}{*}{ Necessity } & $\mathrm{x} 1$ & $300(85.0)$ & $20(5.7)$ & $33(9.3)$ & $1.24 \pm 0.61$ & \multirow{4}{*}{8.652} & \multirow{4}{*}{$.001^{* * *}$} \\
\hline & $\mathrm{x} 2$ & $259(79.2)$ & $22(6.7)$ & $46(14.1)$ & $1.35 \pm 0.71$ & & \\
\hline & $\mathrm{x} 3$ & $239(72.4)$ & $27(8.2)$ & $64(19.4)$ & $1.47 \pm 0.80$ & & \\
\hline & Total & $798(79.0)$ & $69(6.8)$ & $143(14.2)$ & $1.35 \pm 0.72$ & & \\
\hline
\end{tabular}

Note. Values are mean (standard deviation).

${ }^{\mathrm{z}} \mathrm{x} 1$ = Elementary school; $\mathrm{x} 2=$ Middle school; $\mathrm{x} 3=$ High school.

${ }^{\mathrm{y}} \mathrm{y} 1=$ Yes; $\mathrm{y} 2=$ No; $\mathrm{y} 3=$ Need; $\mathrm{y} 4=$ No need; $\mathrm{y} 5=$ Don't know.

${ }^{\mathrm{NS}}$ Non-significant, ${ }^{* * *}$ at $p<.001$ by ANOVA test.

of school garden education service. Regarding the necessity of school garden education service, 798 (79\%) out of 1,010 respondents said it was necessary. This is similar to the results of Kim (2014) in which $81 \%$ of the respondents said it was necessary, indicating that people perceived a high level of necessity of school gardens, similarly to the definition that school gardens can be a teaching strategy (Kim, 2014). On the other hand, 6.8\% (69) responded it was not necessary, suggesting the need to continuously determine and monitor the current state by developing and supplying best practices so that people can find interest (Table 3).

In the different awareness of the necessity of school garden education service, the experience of the respondents who said it was 'necessary' was $1.24 \%$, which was $0.29 \%$ higher than 'not necessary', thereby showing a difference in awareness of necessity depending on experience. As a result of examining the correlation with necessity based on experience, $91.8 \%$ of parents with experience responded that school garden education service was necessary, and $74.0 \%$ of those without experience responded it was necessary. This shows that parents with experience had higher awareness of the necessity of school garden education service, and thus providing experience opportunities in terms of expanding school garden education service is an important factor. The t-test results showed that there was a statistically significant difference at the $95 \%$ confidence level between school garden education service necessity and participation experience in gardening activities (Table 4).

As a result of conducting the $x^{2}$ test to compare the differ- 
ence in awareness and necessity of school garden education service depending on experience, there was a statistically significant result at the $95 \%$ significance level, showing a difference in awareness and necessity depending on participation experience (Table 5). This is similar to the report of the RDA (2014) showing that participating in school gardens have positive effects on health, social, emotional, and environmental factors, thereby increasing the interest among participants so that they are willing to participate whenever they get the chance.

\section{Willingness to pay for the operating expenses of school garden education service}

We provided an explanation there are expenses for school garden education service, such as creating gardens, installing amenities, operating various education programs, and installing other facilities, after which we surveyed the willingness to pay for the operating expenses. The results showed that $54.9 \%$ (554) were willing to pay, but there was no statistically significant difference as a result of one-way ANOVA (Table 6). This is different from the RDA (2014) reporting that $62 \%$ of respondents were willing to pay for the operating expenses of school gardens, but this can be interpreted as parents who enthusiastically want the school garden education service to be provided after paying for the expenses. On the other hand, most respondents not willing to pay thought that this service 'must be created and operated by the finances of the school, local government, and government'. This suggests that, to promote use of school gardens, the government and local governments must provide continuous support and maintenance such as providing financial and material support, and nurturing instructors with expertise and specialized knowledge in operating school gardens.

For willingness to pay depending on experience, $65.2 \%$ of those with experience and $50.8 \%$ of those without experience had willingness to pay, indicating that those who have experience were more willing to pay. The difference depending on the experience of respondents who have will-

Table 4. Differences in perception of the necessity of school garden education services according to the experience.

(unit: number(\%))

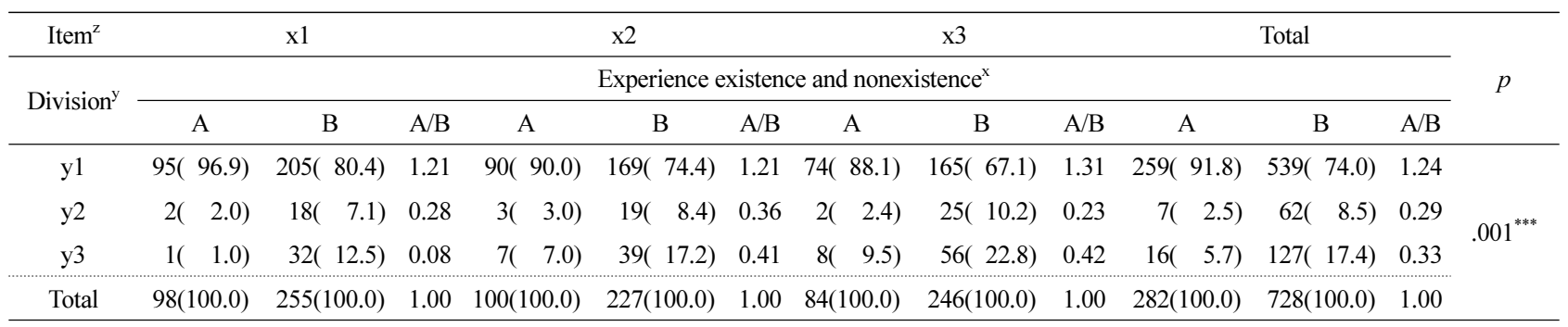

Note. Values are mean(standard deviation).

$\mathrm{z}$ 1 $=$ Elementary school; $\mathrm{x} 2=$ Middle school; $\mathrm{x} 3$ = High school.

${ }^{\mathrm{y}} \mathrm{y} 1=$ Need; $\mathrm{y} 2=$ No need; $\mathrm{y} 3=$ Don't know.

${ }^{\mathrm{x}} \mathrm{A}=$ Experience existence; $\mathrm{B}=$ Experience nonexistence.

**** significant at $p<.001$ by t test.

Table 5. Differences in awareness level and necessity of school garden education services according to the experience.

(unit: number(\%))

\begin{tabular}{|c|c|c|c|c|c|c|c|c|c|c|c|c|c|}
\hline \multirow{2}{*}{ Item $^{\mathrm{y}}$} & & \multicolumn{5}{|c|}{ Awareness level } & \multirow{2}{*}{$x^{2}$} & \multirow{2}{*}{$\mathrm{p}$} & \multicolumn{3}{|c|}{ Necessity } & \multirow{2}{*}{$x^{2}$} & \multirow{2}{*}{$p$} \\
\hline & & y1 & y2 & y3 & $\mathrm{y} 4$ & y5 & & & y6 & y7 & y8 & & \\
\hline \multirow{3}{*}{ Experience } & Yes & $10(1.0)$ & $16(1.6)$ & $97(9.6)$ & $122(12.1)$ & $37(3.7)$ & \multirow{3}{*}{275.776} & \multirow{3}{*}{$.000^{* * *}$} & $259(25.6)$ & $7(0.7)$ & $16(1.6)$ & \multirow{3}{*}{38.882} & \multirow{3}{*}{$.001^{* * *}$} \\
\hline & No & $176(17.4)$ & $250(24.8)$ & $210(20.8)$ & $82(8.1)$ & $10(1.0)$ & & & $539(53.4)$ & $62(6.1)$ & $127(12.6)$ & & \\
\hline & Total & $186(18.4)$ & $266(26.3)$ & $307(30.4)$ & $204(20.2)$ & $47(4.7)$ & & & $798(79.0)$ & $69(6.8)$ & $143(14.2)$ & & \\
\hline
\end{tabular}

Note. Values are mean (standard deviation).

${ }^{\mathrm{y}} \mathrm{y} 1=$ No idea; $\mathrm{y} 2=$ Hardly know; $\mathrm{y} 3=$ Heard; $\mathrm{y} 4=$ Know a little; $\mathrm{y} 5=$ Know well; $\mathrm{y} 6=$ Yes; $\mathrm{y} 7=$ No.

${ }^{* * *}$ significant at $p<0.001$ leveled by chi-square test. 
ingness to pay was 1.28 , which is quite higher than 0.71 of respondents who do not (Table 7). This shows that respondents with actual experience showed more active intent to participate than those without experience in terms of necessity of school garden education service.

As a result of conducting a paired sample t-test to verify the relationship between school garden education service experience and willingness to pay, there was a statistically significant difference at the $95 \%$ confidence level (Table 8). This supported the hypothesis that 'willingness to pay for school garden education service may vary depending on experience.'

We examined the willingness to pay among parents willing to pay for operating expenses with income tax (direct tax) or individual consumption tax (indirect tax) and found out that the amount among those with experience was maximum 100,000 KRW and minimum $500 \mathrm{KRW}$, and the amount among those without experience was maximum $120,000 \mathrm{KRW}$ and minimum $10 \mathrm{KRW}$. The average amount willing to pay in income tax was $13,193 \mathrm{KRW}$, and those without experience $(13,399 \mathrm{KRW})$ showed a slightly bigger amount than those with experience (12,780 KRW). This was higher than the results of the RDA (2014) that reported 5,000-10,000 KRW and Kim (2014) that reported 3,000-10,000 KRW, and was statistically significant as a result of one-way ANOVA (Table 9).

When the means of payment was individual consumption tax (indirect tax), the average tax rate willing to pay was

Table 6. Willingness to pay the operating cost of school garden education service.

(unit: number(\%))

\begin{tabular}{cccccc}
\hline Item $^{\mathrm{z}}$ & Yes & No & Mean \pm SD & F & Significant \\
\hline x1 & $207(58.6)$ & $146(41.4)$ & $1.41 \pm 0.49$ & & \\
x2 & $182(55.7)$ & $145(44.3)$ & $1.44 \pm 0.50$ & 2.640 & $.072^{\mathrm{NS}}$ \\
x3 & $165(50.0)$ & $165(50.0)$ & $1.50 \pm 0.50$ & $1.45 \pm 0.50$ & \\
Total & $554(54.9)$ & $456(45.1)$ & & \\
\hline
\end{tabular}

Note. Values are mean(standard deviation).

zx1 = Elementary school; x2 = Middle school; x3 = High school.

${ }^{\mathrm{NS}}$ Non-significant by ANOVA test.

Table 7. Operating experiences of school garden education services according to the experience and willingness to pay. (unit: number(\%))

\begin{tabular}{|c|c|c|c|c|c|c|c|c|c|c|c|c|}
\hline Item $^{2}$ & & $\mathrm{x} 1$ & & & $\mathrm{x} 2$ & & & $\mathrm{x} 3$ & & & Total & \\
\hline \multirow{2}{*}{ Division $^{y}$} & \multicolumn{12}{|c|}{ Experience existence and nonexistence ${ }^{\mathrm{x}}$} \\
\hline & A & B & $\mathrm{A} / \mathrm{B}$ & A & B & $\mathrm{A} / \mathrm{B}$ & A & B & $\mathrm{A} / \mathrm{B}$ & A & B & $\mathrm{A} / \mathrm{B}$ \\
\hline y1 & $68(69.4)$ & $139(54.5)$ & 1.27 & $63(63.0)$ & $119(52.4)$ & 1.20 & $53(63.1)$ & $112(45.5)$ & 1.39 & $184(65.2)$ & $370(50.8)$ & 1.28 \\
\hline y2 & $30(30.6)$ & $116(45.5)$ & 0.67 & $37(37.0)$ & $108(47.6)$ & 0.78 & $31(36.9)$ & $134(54.5)$ & 0.68 & $98(34.8)$ & $358(49.2)$ & 0.71 \\
\hline Total & $98(100.0)$ & $255(100.0)$ & 1.00 & $100(100.0)$ & $227(100.0)$ & 1.00 & $84(100.0)$ & $246(100.0)$ & 1.00 & $282(100.0)$ & $728(100.0)$ & 1.00 \\
\hline
\end{tabular}

Note. Values are mean(standard deviation).

zx1 = Elementary school; $\mathrm{x} 2$ = Middle school; $\mathrm{x} 3$ = High school.

${ }^{\mathrm{y}} \mathrm{y} 1=$ Yes; $\mathrm{y} 2=$ No.

${ }^{\mathrm{x}} \mathrm{A}=$ Experience existence; $\mathrm{B}=$ Experience nonexistence.

${ }^{* * *}$ significant at $p<.001$ by t test.

Table 8. Relationship between the experience and willingness to pay of school garden education services.

\begin{tabular}{cccccc}
\hline Item & $\mathrm{n}$ & Mean \pm SD & $\mathrm{t}$ & $\mathrm{df}$ & $p$ \\
\hline Experience & 1010 & $1.72 \pm 0.45$ & 13.683 & 1009 & $.000^{* * *}$ \\
Willingness to pay & 1010 & $1.45 \pm 0.50$ & & \\
\hline
\end{tabular}

significant at $p<0.001$ by $\mathrm{t}$ test. 
Table 9. Amount of intention to pay school garden education services using income tax as a payment method. (unit : won)

\begin{tabular}{|c|c|c|c|c|c|c|c|c|c|c|c|c|c|c|}
\hline Item $^{\mathrm{z}}$ & & $\mathrm{x} 1$ & & & $\mathrm{x} 2$ & & & $\mathrm{x} 3$ & & & Total & & \multirow{3}{*}{$\mathrm{F}$} & \multirow{3}{*}{$p$} \\
\hline \multirow{2}{*}{ Division } & \multicolumn{12}{|c|}{ Experience existence and nonexistence ${ }^{\mathrm{x}}$} & & \\
\hline & A & B & $\mathrm{T}$ & A & B & $\mathrm{T}$ & A & $\mathrm{B}$ & $\mathrm{T}$ & A & B & $\mathrm{T}$ & & \\
\hline Mean & 13,301 & 15,003 & 14,444 & 12,579 & 14,315 & 13,714 & 12,349 & 10,434 & 11,049 & 12,780 & 13,399 & 13,193 & \multirow{5}{*}{3.870} & \multirow{5}{*}{$.021^{*}$} \\
\hline \multirow{2}{*}{ Max } & 100,00 & 120,00 & 120,00 & 100,00 & 100,00 & 100,00 & 100,00 & 120,00 & 120,00 & 100,00 & 120,00 & 120,00 & & \\
\hline & 0 & 0 & 0 & 0 & 0 & 0 & 0 & 0 & 0 & 0 & 0 & 0 & & \\
\hline Min & 500 & 500 & 500 & 500 & 10 & 10 & 500 & 100 & 100 & 500 & 10 & 10 & & \\
\hline SD & 14,933 & 19,169 & 17,870 & 14,375 & 19,746 & 18,046 & 14,284 & 14,635 & 14,507 & 14,484 & 18,178 & 17,030 & & \\
\hline
\end{tabular}

Note. Values are mean(standard deviation).

z $1=$ Elementary school; $\mathrm{x} 2=$ Middle school; x3= High school.

${ }^{\mathrm{x}} \mathrm{A}=$ Experience existence; $\mathrm{B}=$ Experience nonexistence; $\mathrm{T}=$ Total.

"significant at $p<0.05$ by ANOVA test.

Table 10. Tax rate of intention to pay school garden education services using individual consumption tax as a payment method

(unit : \%)

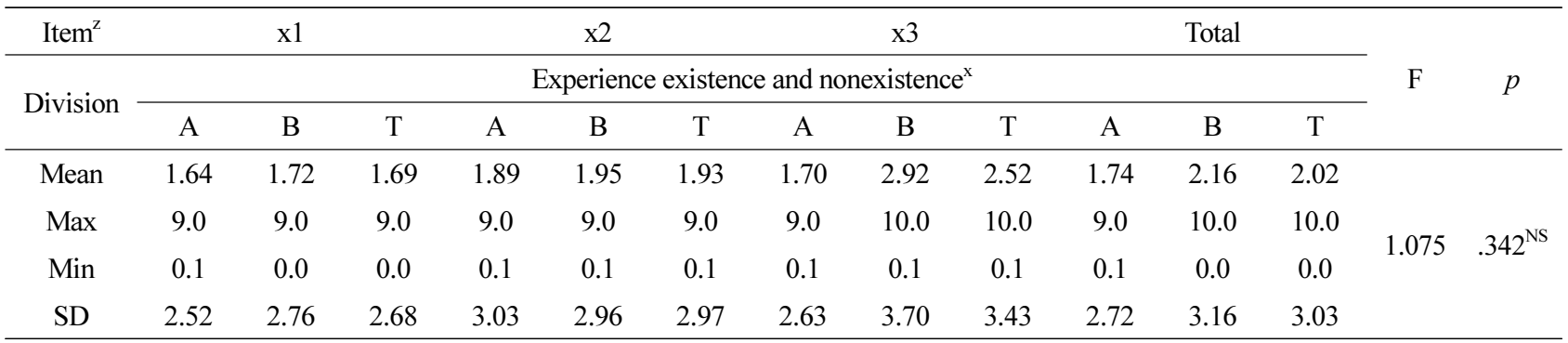

Note. Values are mean(standard deviation).

${ }^{\mathrm{z}} \mathrm{x} 1$ = Elementary school; $\mathrm{x} 2=$ Middle school; $\mathrm{x} 3$ = High school.

${ }^{\mathrm{x}} \mathrm{A}=$ Experience existence; $\mathrm{B}=$ Experience nonexistence; $\mathrm{T}=$ Total

${ }^{\mathrm{NS}}$ Non-significant by ANOVA test.

$2.02 \%$. Like income tax, the tax rate among those without experience $(2.16 \%)$ was higher than those without experience $(1.74 \%)$, and the result was not statistically significant as a result of one-way ANOVA (Table 10). This tax rate difference between those with experience at $0.1-9.0 \%$ and those without experience at $0-10 \%$ may be due to the fact that those who experienced school garden education service perceived higher necessity of the service and showed higher willingness to pay, but set the amount or tax rate lower because they are aware of the operation status through actual experience.

\section{Conclusion}

To determine the awareness of school garden education service as well as intent to participate and willingness to pay for the service among 1,010 parents of elementary, middle, and high school students in 5 major districts, this study conducted an online survey through a specialized research institute from October 22 to 26, 2020. The results of obtaining the frequency and weight of each measurement item and determining the pros and cons about education service, intent to participate, and willingness to pay depending on school garden experience are as follows.

First, there were 494 male (48.9\%) and 516 female (51.1\%) respondents, with slightly more women than men. Most of the respondents were in their 40s $(722,71.5 \%)$, and 359 respondents (35.5\%) lived in Gyeonggi/Gangwon/Incheon. Most were salaried employees $(577,57.1 \%)$, and their highest level of education was mostly university students/graduates $(755,74.8 \%)$. For average monthly income, most re- 
spondents earned 4-4.99 million KRW (230, 22.8\%), and the average number of children was 1.83 , with slightly more male children $(52.8 \%)$ than female.

Second, $55.3 \%$ of the respondents were aware of school garden education service, but the mean was low at 2.66. Only $27.9 \%$ of the respondents have experience participating in relevant service, and $79 \%$ of all respondents said school garden education service was necessary. Depending on experience, $91.8 \%$ of parents with experience said the service was necessary, whereas $74.0 \%$ of those without experience said it was necessary, indicating how important it is to provide opportunities to experience this service in terms of expanding school garden education service. The necessity of school garden education service necessity and participation experience in gardening activities showed a statistically significant difference at the $95 \%$ confidence level.

Third, $54.9 \%$ of all respondents said they were willing to pay for the expenses of school garden education service such as creating gardens, installing amenities, operating various education programs, and installing other facilities. $65.2 \%$ of those with experience and $50.8 \%$ of those without experience were willing to pay, indicating that the former were more willing to pay for school garden education service. As a result of conducting a paired sample t-test to determine the relationship between school garden education service experience and willingness to pay, there was a statistically significant difference at the $95 \%$ confidence level. Moreover, the average amount that the respondents were willing to pay when the means of payment was income tax was 13, $193 \mathrm{KRW}$, and the tax rate was $2.02 \%$. Those with experience perceived higher necessity of school garden education service than those without experience and also showed higher willingness to pay, but they actually set lower amount or tax rate since they are aware of the actual operation status.

This study has limitations in that the survey was conducted online in a contactless form due to COVID-19 and thus the items of the questionnaire were limited. Nonetheless, to promote use of school gardens, the government and local governments must provide continuous support and maintenance such as providing financial and material support, and nurturing instructors with expertise and specialized knowledge in operating school gardens. The creation and utilization of school gardens are expected to increase continuously due to the diverse effects of school gardens as well as the social atmosphere, raising an urgent need to establish valuation indicators for school garden education service to continuously operate and maximize the effects of school gardens. The results of this study can be used to develop evaluation indicators for school garden service and even evaluate socioeconomic values in further research.

\section{References}

Green growth committee(GGC). 2012. Green education development plan research; focusing on school garden education. Green growth committee result report, Seoul, Korea:GGC.

Hong, E.S and J.H. Kim. 2017. The effect of the school farm program on the personality of elementary school students. J. Korean Pract. Arts Educ. 23(1):163-186.

Hong, I.K., H.K. Yun, Y.B. Jung, and S.M. Lee. 2020. Derivation of indicators for value assessment of school gardens. J. People Plants Environ. 23(4):433-443. http:// doi.org/10.11628/ksppe.2020.23.4.433

Jang, Y.N., S.J. Jeong, K.S. Han, G.M. Kim, I.J. Choi, and J.N. Heo. 2017. Set up and running status of school gardening at elementary schools: Focus on Jeollabuk-do. Korean J. Community Living Sci. 28(4):613-623. http://doi.org/10.7856/kjcls.2017.28.4.613

Jeong, Y.O and J.H. Lee. 2013. The effect of the horticultural activity on the sociality and friend relation of elementary school students. J. Korean Pract. Arts Educ. 26(3):41-58.

Kim, K.R, and Y.O. Jeong. 2008. The effect of vegetable gardening on society among elementary school students. J. Korean Pract. Arts Educ. 21(1):153-165.

Kim, Y.J. 2014. Influence of construction and use of school garden in elementary school on recognition of teachers, parents, and students. Master's thesis, Korea University, Seoul, Korea.

Kwack, H.R. and H.C. Park. 2017. Adoption of emotional intelligence education in elementary horiculture education and survey of it's recognition to teachers. J. Korean 
Pract. Arts Educ. 30(1):107-124.

Kim, Y.K. 2014. Analysis of current operational state of vegetable gardens by elementary school and plans for activation. Master's thesis, Seoul National University of Education, Seoul, Korea.

Lee, C.S., B.H. Lee, and S.R. Yang. 2014. Development of the Agricultural competitiveness index. Korea. J. Agri. Manag. Policy. 41(4):666-700.
Ministry of Agriculture, Food and Rural Affairs(MAFRA). 2017. 2016 urban farming status report, MAFRA, Sejong, Korea.

Rural Development Administration(RDA). 2014. The study on school farm for experienctial education in primary school. National Institute of Horticultural Herbal Sci. final report, Suwon, Korea:RDA. 